\title{
Seeking Best Practices And Meeting The Needs Of The English Language Learners: Using Second Language Theories And Integrating Technology In Teaching \\ Nan Li, Ph.D., Claflin University, USA
}

\begin{abstract}
A noticeable national trend in schools today is the rapid increase in the number of the English language learners. The widespread use of technology in classrooms is another trend today. In combining these two trends, this paper discusses the best practices that teachers can use in classrooms to work effectively with English language learners (ELLs) by integrating technology combined with second language theories. Specifically, the paper focuses on three aspects of the discussion. First, it provides the background information on the ELL school population and the growth. Second, it discusses four practices working with ELLs. These four practices are increasing comprehensible input, encouraging social collaboration, relating to the real world and providing supportive learning environments. Each is discussed with integration of technology combined with second language (L2) theories. Finally, the paper urges educators to acknowledge the two trends and see best instructional practices to meet the needs of the ELLs and all students.
\end{abstract}

Keywords: English Language Learners; Teaching Technology; Second Language Theories

\section{INTRODUCTION}

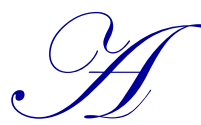

noticeable trend in schools today that attracts the attention in the field of education is the increase of the school enrollment of the English language learners (ELLs). Technology as a tool used for teaching in classrooms is a growing trend. The technology trend is evidenced in the field of education through a familiar terminology called educational technology and the ELL trend is evidenced by the fast increase in the number of ELL students in schools throughout the nation' classrooms. Most teachers and educators are already aware of these two noticeable trends. Yet, one critical question to be discussed is: How can we use the power of technology and combine it with second language (L2) theories in teaching to work with the ELLs effectively in today's diverse classrooms? This paper intends to answer this question. It discusses four best practices that teachers can use in classrooms through integrating technology and combining L2 theories to meet the needs of the ELLs.

\section{ELL BACKGROUND INFORMATION}

With the elimination of Johnson-Reed Act in 1968, an immigration law that was created in 1924 with a quota system to discriminate against non-European immigrants, immigration population in the United States has quickly increased. Since the 1970s, the immigration population has presented more diversity, i.e., more immigrants are from non-European countries. This immigration demographic change affects school population. As the ELL school population has increased rapidly, it is also largely from non-European countries (Ovando, Collier, \& Combs, 2005). Data reveals that the ELL school enrollment growth was 105 percent from 1995 to 2005 when the general school population growth was only 12 percent (NCELA, 2008). Currently, over five million school-aged students are ELLs (NCES, 2010; Zelasko \& Antunez, 2005). With this demographic in schools, teachers in classrooms face a challenge in terms of knowing L2 teaching strategies and working effectively with the ELLs. 
This challenge becomes even greater when the number of the ELL population continues increasing and yet the teacher force remains relatively unchanged. Data reveal the continued shortage of the well-prepared teachers who are equipped with the L2 theoretical knowledge and teaching skills to meet the needs of the ELLs (NCES, 2010). Therefore, it is important to seek the best practices and meet the needs of the ELL population. As teleology is increasingly integrated into classrooms, we can take the advantage that technology offers and combine it with the power of the L2 theories in teaching to meet the needs of the ELLs. In the following sections, four best practices for working effectively with the ELLs are discussed with technology integration.

\section{BEST PRACTICES WORKING WITH THE ELLS}

Best practices in general refer to what works in a particular situation or environment (Gambrell, Morrow, \& Pressley, 2007). We believe that a best practice may include any technique or method that, through experience and research, has proven to be reliable and can lead to a desired result. The best practice in teaching must, first of all, involve the commitment of a teacher who is willing to use the knowledge and techniques at his or her disposal to ensure student success. It is imperative that teachers are committed to advance their knowledge and skills for the purpose of promoting student learning. Four best practices here are intended to help teachers work with the ELLs successfully and to increase the effectiveness in classroom instruction. These four practices are:

- Increasing comprehensible input,

- $\quad$ Encouraging social collaboration,

- $\quad$ Relating learning to the real world and

- $\quad$ Providing supportive learning environments.

\section{INCREASING COMPREHENSIBLE INPUT}

A critical concept for learning a second-language is to increase comprehensible input and this comes from L2 acquisition theories. According to this theory, learners must be able to understand the essence of what is being said or presented to them, i.e., the message must be comprehensible. In order to increase comprehension for ELLs, teachers need to use various teaching techniques and strategies to ensure that ELLs understand the materials presented to them (Bylund, Abrahamsson, \& Hyltenstam, 2012). However, comprehensible input does not mean that teachers should use oversimplified words to teach ELLs. In fact, the ELLs learn a new language best when they receive L2 input that is just a bit more difficult than they can easily understand. In other words, the ELLs do not need to understand every word or piece of information presented to them, but they do need to have a solid overall grasp on the material. Linguists also believe that effective language instruction depends on providing input at one level of complexity beyond the ELLs' level of linguistic competence, often expressed as "The i+1 formula" (Krashen,1985; Schütz, 2007). Based on these theories, the language that contains one level of linguistic complexity beyond the learners' level provides a challenge that helps L2 acquisition. Therefore, teachers must be sure to make instruction comprehensible and yet not to use oversimplified language. Introducing new vocabulary and concepts to ELLs is essential. While introducing new vocabulary and advanced topics, teachers should use a variety of teaching techniques to help the ELLs understand the materials presented to them.

Several strategies for increasing comprehension for ELLs include:

- $\quad$ Provide relevant contexts. To make learning effective, teachers need to help the ELLs digest new concepts within the relevant contexts. For example, before exposing ELLs to new concepts, teachers should provide background knowledge and contextual information, e.g., using examples and providing variations to explain concepts to help ELLs learn the new vocabulary and construct new conceptions.

- $\quad$ Connect learning to prior knowledge and experiences. Teachers do not have to be experts in their ELLs' lives and cultures. Yet, teachers do need to understand the dynamics of connecting learning to students' prior knowledge and existing experiences. Teachers can learn about ELLs by listening attentively to their stories, by visiting ELL homes and communities, and by participating in cultural events. When learning is connected to student experiences, instruction becomes more meaningful and motivational to ELLs.

- Using visual aids and physical artifacts. Visual aids and physical artifacts (e.g., photos, pictures, graphics, images, body gestures, language intonation and cue, and other aids) can convey meaning effectively. The 
notion of using physical aids to assist L2 learning comes from the L2 theory call total response. This theory suggests L2 teaching be coordinated with physical movement. It is believed that the more often memory connection is traced, the stronger it becomes. Visual aids function especially well when a piece of text cannot convey a concept. For example, a teacher can use gestures, pictures, and images to demonstrate a movement, such as closing the door, sitting down, or standing up, to help the ELLs understand concepts in L2.

Technology is a convenient tool to increase comprehensible input and helps incorporate the abovementioned strategies to provide the demonstration of the concrete examples of concepts. For instance, multimedia CDs, digital tutorials, and the Web links provide an endless source of pictures, videos, sound, animation, and multimedia that can help the ELLs to learn the content within a meaningful context (Dukes, 2005). Using a specific example about Vasco da Gama's voyages from Portugal to India, a simple verbal description of the trip may not sufficient for the ELLs to have a solid understanding. It is also impossible that a teacher takes the students to Portugal or recreate the voyage. Yet, technology can provide help by using the website link to the European Voyages of Exploration (www.ucalgary.ca/applied_history/tutor/eurvoya/vasco.html). The link has animated maps with virtual tours and helps not only ELLs but all students who cannot live through such a life experience.

\section{ENCOURAGING SOCIAL COLLABORATION}

Opportunities to interact with peers help ELLs absorb the new concepts (Bylund, Abrahamsson, \& Hyltenstam, 2012). In the learning process, teachers need to encourage the ELLs and provide opportunities for them to interact and collaborate with peers so that the ELLs have an opportunity to express ideas and thoughts through social collaboration with peers. Cooperative learning activities provide such opportunities that allow ELLs to work with peers and it thus helps accomplish learning goals. When ELLs are communicating with peers and teachers, the communication provides not only input but also output (Watkins, 2005). This means that the ELLs are not only awarded to use correct grammar and syntax to express in L2 but they also need to understand the message (input) conveyed to them through interaction. Thus, teachers need to keep in mind when designing a lesson for students to work together and encourage classroom interaction. To continually modulate and clarify the language of instruction, teachers must also allow ELLs to ask questions and make sure that they understand the content. Teachers can increase peer interaction by providing opportunities for ELLs to share their cultures and experiences. Using language through peer collaboration helps increase ELLs' receptive and expressive language skills.

Technology is an amazing tool to provide opportunities for ELLs to interact with peers in class as well as the real-life audience outside of classrooms, cities, or even worldwide (Dukes, 2005). Teachers can assign ELLs to interact with classmates by working on projects or activities together, such as working on a software program in pairs, writing and revising a story with a partner, or creating an "electronic book report" using multimedia software such as PowerPoint. In all of these instances, students benefit from one another's knowledge, practice their verbal skills through conversing with one another whether it is about how to use the technology or the instructional content itself, and practice listening comprehension by listening and responding to their partners. Students can also interact with people outside of their classrooms by using "safe" e-mail or chat room programs or by using videoconferencing to collaborate with students outside of classrooms across the globe. For example, one option for safe e-mail is ePALS (see www.epals.com), which is one of the world's largest K-12 learning networks.

\section{RELATING LEARNING TO THE REAL WORLD}

Relating learning to the real world allows all students to explore, discuss, and construct concepts and relationships in contexts that is relevant to the real-world and meaningful to the students (Donovan, Bransford, \& Pellegrino, 1999). Teachers can use some authentic learning activities to involve the ELLs in complex tasks that require higher level thinking skills. Relating learning to the real world has two particular benefits for ELLs. First, the learning that is connected to the real world is more likely to equip ELLs for English communication in the real life. Second, ELLs are more likely to be engaged actively in activities that they see as relevant to their own lives. The classroom vs. real world debate arose after realizing over decades that ELL students could produce accurate communication in the classroom as part of a scripted exercise; yet, they were often unable to communicate successfully in English outside the classroom. The conclusion was that having ELLs learn English only through scripted 
dialogues and fill-in-the-blank grammar exercises in the classroom was not enough. Therefore, making learning authentic is crucially important and ELL students must have the opportunities to be prepared in the classroom for the challenge that they would face under real-life circumstances.

When developing authentic learning experiences, a teacher should identify a problem or situation that the students are interested in addressing and through which students can learn problem-solving skills. The teacher must also consider the students' abilities, their learning objectives, and educational goals. It is important that teachers maintain a balance. Jim Cummins, L2 linguist, theorized two types of English proficiency and stated that ELLs acquire two types of English, which are BICS and CALP (Cummins, 2000, 1997; Haynes, 2004). BICS stands for Basic Interpersonal Communication Skills, i.e., an ELL's L2 conversational fluency. CALP stands for Cognitive Academic Language Proficiency, i.e., an ELL's L2 academic proficiency. BICS are used in informal situations such as social exchanges. CALP is used in more formal, academic situations, such as understanding chemistry or a social studies lesson. One may tend to relate BICS more with real-world communication in that much of our daily conversation is spontaneous and is either social or task-oriented in nature. While this is true, CALP is also reality based in nature in that students need CALP to be able to learn new academic skills for their overall educational advancement and to equip them for real-life tasks like securing employment. Proficiency in both BICS and CALP is important for ELLs' success, and instruction should incorporate activities that target both. Thus, teachers must dedicate instructional activities to incorporate both BICS and CALP and be skillful as they plan lessons to make learning authentic. For example, if a teacher is teaching students about economic concepts, such as supply and demand, considering having the students demonstrate their understanding by performing a task that will interest them, e.g., mocking an online company that sells and downloads music files.

Technology can help make authentic learning practical by providing convenient access to the informationgathering and presenting tools that students need and that assist teachers in making learning authentic. The Web is an endless source for authentic English language communication. Students can go to the relevant Website to listen to sound bytes of authentic conversations on varying topics, watch video clips of current news headlines, or listen to popular American music. The Internet also provides endless opportunities for spontaneous communication through such Web-based tools as e-mail, online chat, or videoconferencing technology. Visit the Voice of America's "Special English" homepage for newscasts and other materials for ELL students, for instance, from the relevant websites (e.g., www.voanews.com/specialenglish/index.cfm). Check out the Global Schoolhouse homepage for numerous opportunities to videoconference with other classrooms around the world (www.globalschoolhouse.com). Teachers might also give their ELL students the opportunity to publish their own work for an authentic Web audience by "blogging" (www.blogger.com). Blog stands for "Web log" and it is the online version of a journal or diary that can help improve the writing skills for ELL students. In addition, students can also use word processors, data bases, spreadsheets, desk top publishers, HTML to create pages to publish on the World Wide Web, and multimedia authoring tools such as Power Point or HyperStudio. Indeed, the value of authentic learning activities when used in tandem with technology has much to offer the teacher and the students.

\section{CREATING A POSITIVE LEARNING ENVIRONMENT}

Learning is influenced by many factors and learning environment is an important one. Teachers must be cognizant of this fact and understand that they are responsibility to provide a healthy learning environment for all students to learn productively (Muijs, Harris, Chapman, Stoll, 2004). Theoretically, a positive learning environment is conductive and helpful especially for ELL students. According to L2 acquisition theories, acquiring a L2 involves many affective factors. An affectively supportive environment is necessary for ELL students because they respond to a new language positively only when environments are encouraging, supportive, motivating, and giving them confidence (Krashen, 1985; Ovando, Collier, \& Combs, 2005). Affective factors usually refer to a student's emotions and include aspects such as the student's motivation to learn, self-esteem, and comfort level in the classroom. Educators agree that affective factors can have a significant influence on ELL students' learning. A poor self-image, low motivation, and self-consciousness are all factors that can influence a student's learning negatively. The most effective learning environments are those that are supportive and open, allow for mistakes without ridicule, and encourage students to try, even if they might make a mistake. Thus, in designing learning settings, educators should consciously create friendly, positive, less tense styles of teaching within an atmosphere that lowers students' anxiety and provides affective support for ELLs and all students to learn productively. 
The technology is an excellent tool that gives students the chance to practice English skills without worrying about the affective aspects or responses of other classmates and even the teacher. As Wiburg and ButlerPascoe (1999) explains that the non-judgmental nature of the computer makes it an ideal tool to help second language learners feel sufficiently secure to make and correct their own errors without embarrassment or anxiety. Technology can also improve students' motivation to learn (Butler-Pascoe, 1997). While some students enjoy traditional paper-and-pencil writing, getting to use clip art, word art, colors, and fonts can be more creative. Although we do not suggest giving up paper and pencil, yet it gives more motivation to integrate technology in teaching in the classroom. If a traditional bulletin board display of what a student learned in a particular subject isn't appealing, perhaps an interactive PowerPoint presentation, companied by sound, graphics and animation, will do a more perfect job. The opportunity that technology affords students to create crisp-looking, visually appealing products can provide the extra help needed to capture students' interest.

\section{A FINAL WORD}

This paper discusses four best practices to help teachers in classrooms. The four practices are increasing comprehension, encouraging interaction, making learning authentic and creating a positive learning environment. Each practice is discussed with technology integration. Two trends in education are the rapid growth to the ELL population and the advancement of technology and teachers must acknowledge the trends and adapt instruction to meet the needs of diverse classrooms today. Instruction is an interaction that involves teachers, students, and content. Instruction also takes place in an environment that can offer both constraints and opportunities (Cohen, Raudenbush, \& Ball, 2003). Educators need to be thoughtful in planning lessons and view instruction as an interactive tool to reduce constraints, optimize opportunities, and maximize positive influences. Technology offers opportunities for teachers to accomplish the educational goals. Education is a bridge to enhance communication, understanding, and the human potential of all students including ELLs (Fass, 1989). As school diversity increases, the challenge for teachers also increases. It is thus crucial that educators continue exploring and acquiring the knowledge and skills necessary to meet the needs of ELLs and all students.

\section{AUTHOR INFORMATION}

Dr. Nan Li is Associate Professor at Claflin University, USA. Dr. Li is currently managing three grant project (3.2 million) with 2.5 grant projected funded by U.S. Department of Education. Dr. Li has presented at international and national conferences, which include American Educational Research Association (AERA) and National Association for Multicultural Education (NAME) international conferences, for her research with the focus on academic success of minority students. Her recent publications include journal articles and book chapters that advocate promoting the academic success for minority students. E-mail: nli@ claflin.edu

\section{REFERENCE}

1. Bylund, E, Abrahamsson, N. \& Hyltenstam, K. (2012). Does first language maintenance hamper nativelikeness in a second language? Studies in second language acquisition, 34(2), 225-241.

2. Butler-Pascoe, M. E. (1997, May-June). Technology and second language learners. American Language Review, 1(3). Retrieved April 18, 2011, from www.languagemagazine.com/internetedition/mj97/eets20.html

3. Cohen, D., Raudenbush, S., \& Ball, D. (2003). Resources, instruction, and research. Educational Evaluation and Policy Analysis, 25 (2), 1-24.

4. Cummins, J. (2000): Language, power, and pedagogy. Bilingual children in the crossfire. Clevedon, England: Multilingual Matters.

5. Donovan, M. S., Bransford, J. D., \& Pellegrino, J. W. (1999). How people learn: Bridging research and practice. Washington, DC: National Academy Press.

6. Dukes, C. (2005). Best practices for integrating technology in English language instruction. ELL \& Technology-Southeast Initiatives Regional Technology in Education Consortium, 7(1), 3-6.

7. Fass, P. (1989). Outside in: Minorities and the transformation of American education. New York: Oxford University Press. 
8. Gambrell, L.B., Morrow, L.M., \& Pressley, M. (2007). Best Practices in Literacy Instruction. New York: Guilford Press Publication.

9. Haynes, J. (2004). Explaining BICS and CALP. Retrieved April 18, 2005, from www.everythingesl.net/inservices/bics_calp.php

10. Krashen, S. D. (1985). Inquiries and insights: Second language teaching, immersion, and bilingual education literacy. Englewood Cliffs, NJ: Alemany Press.

11. Muijs, D., Harris A., Chapman C., and Stoll, L. (2004). Improving schools in socioeconomically disadvantaged areas--a review of research evidence. School Effectiveness and School Improvement, 15(2), 149-175.

12. National Center for Education Statistics. (2010). The Condition of Education 2010 (NCES 2010-028). U.S. Department of Education. Washington, DC: U.S. Government Printing Office.

13. National Clearinghouse for English Language Acquisition. (2002). Survey of the States' Limited English Proficient Students and Available Educational Programs and Services Summary Report (2000-2001). Washington, DC: NCELA

14. Ovando, C. J., Collier, V. P., \& Combs, M. C. (2003). Bilingual \& ESL classrooms: Teaching in multicultural contexts. New York: McGraw Hill.

15. Schütz, R. (2007). Stephen Krashen's Theory of Second Language Acquisition. English Made in Brazil. Retrieved from online at http://www.sk.com.br/sk-krash.html

16. Wachet, H.K. (2002). Student evaluation of college teaching effectiveness: A brief review. Assessment and Evaluation in Higher Education, 23(2), 191-211.

17. Watkins, R. (2005). 75 e-Learning Activities: Making Online Learning Interactive. San Francisco: Pfeiffer.

18. Wiburg, K., \& Butler-Pascoe, M.E. (1999). Constructivist uses of technology for second language teaching. In edited by Willis, J \& Willis, D. Technology and Teacher Education Annual, Journal of the Association for Advancement of Computers in Education (AACE).

19. Zelasko, N., \& Antunez, B. (2005). If your child learns in two languages: A parent's guide for improving educational opportunities for children acquiring English as a second language. Washington, DC: National Clearinghouse for Bilingual Education. 